\title{
空間及び波数領域情報を利用した 平板構造物の損傷検出手法に関する研究
}

\author{
古川 愛子 1 ・児島 啓太 2 ・清野 純史 3 \\ 1正会員 京都大学大学院准教授 地球環境学堂（广615-8540 京都市西京区京都大学桂） \\ E-mail:furukawa.aiko.3w@kyoto-u.ac.jp \\ 2正会員 京都大学大学院 工学研究科修士課程（广615-8540 京都市西京区京都大学桂） \\ E-mail: kojima.keita.1118@gmail.com \\ 3 正会員 京都大学大学院教授 地球環境学堂（广615-8540 京都市西京区京都大学桂） \\ E-mail:kiyono.junji.5x@kyoto-u.ac.jp
}

\begin{abstract}
本研究では, 波動伝播を利用した平板構造物の損傷検出手法を提案する。平板状の構造物を伝わる波は Lamb波と呼ばれ，減衰が小さく長距離伝播し易いため一度に広いエリアの点検が期待できる。しかし， Lamb波は多くのモードを有し, かつ各モードそれぞれに分散性があることから, 計測波形の解釈が困難 である. 本研究では, 1次モードだけが発生する周波数帯を利用することにして多モードの発生を抑制す るが，このような周波数帯では損傷の大きさに比べて波長が十分に短くないため，加振点から直接伝わる 直達波と損傷部で反射して伝わる反射波とが混在してしまう。さらに，反射波は直達波に比べて振幅が小 さいため, 反射波を判別するのが困難である. この問題を解決するため, 格子状に配置した複数の計測点 で応答を計測し, 空間領域における情報のみならず, 波数領域における情報も利用することによって, 直 達波と反射を分離し, 反射波の到来方向および到来時間を推定し, 損傷を検出する手法を提案する.
\end{abstract}

Key Words : damage detection, Lamb wave, space domain, wave-number domain, plate structure

\section{1. はじめに}

都市部の道路橋では，軽量で施工工期が短いなどの利 点を生かし，数多くの鋼床版が採用されているが，金属 疲労が原因と思われる亀裂の発生が確認されており ${ }^{1)}$, 目視で確認できないリブの奥側に亀裂が位置する場合も ある．損傷状態を把握するための手段として，波動伝播 を利用するものがある．鋼板などの平板状の構造物を伝 わる波はLamb波と呼ばれ2)33,4)，減衰が小さく長距離伝播 し易いため一度に広いエリアの点検が期待できる. しか し，Lamb波は多くのモードを有し，かつ各モードそれ ぞれに分散性があることから，計測波形の解釈が困難で ある.1次モードだけが発生する周波数帯を利用すれば, 多モードの発生を抑制できるが，このような周波数帯で は損傷の大きさに比べて波長が十分に短くないため，加 振点から直接伝わる直達波と損傷部で反射して伝わる反 射波とが混在してしまう。ささらに，反射波は直達波に比 べて振幅が小さいため，反射波を判別するが困難である。

筆者らは，平板とリブ付の平板を対象に，時間反転法 5), 灰利用し，反射波の存在を特定しやすくする方法につ
いて検討した．時間反転とは，音声や信号を後ろから前 へと逆再生することである．時間反転法は，観測波形を 時間反転させて媒質に逆伝播させることで元の波形を再 現する手法として, Fink によって音響場に適用 7)され,

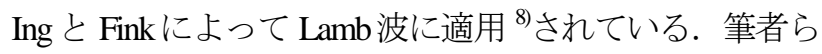
は，損傷のない場合とある場合とで，時間反転させて再 現した波形の形状が異なることを利用して，損傷の有無 と損傷の位置を推定する手法を提案した 9). 構造物のあ る点（A 点とする）に衝撃波（入力波）を与え，別の点 （B 点とする）で応答を計測し，その応答を時間反転し た時刻歴波形を $\mathrm{B}$ 点に再度入力し, その再入力波に対 する A 点での応答 (再現波) を求めると，損傷がない 場合は入力波と再現波の形状は相似形，損傷がある場合 は形状が異なることを利用するものである。しかし，反 射波の影響を明瞭に区別するのは困難であった。

このような，直達波と相対的に振幅の小さい反射波が 時間領域で重なってしまい区別することが困難となる問 題を解決するため，本研究では，格子状に配置した複 数の計測点で応答を計測する方法を提案する. 既往の研 究において, 格子状に配置した複数の計測点で応答を計 
測する場合は, 格子内に存在する損傷の検出を対象とし ている ${ }^{10}$ が，本研究では格子内の損傷だけでなく, 格子 外の損傷の検出も目指す.

格子状に計測したデータは，時間を $t$, 格子の直交す る 2 つ座標を $x, y$ とすると, $t, x, y$ の 3 次元の時間-空間 領域のデータである. 3 次元フーリエ変換によって時間 $t$ を周波数 $\omega$ に, 座標 $x, y$ を波数 $k_{x}, k_{y}$ に变換すれば，周波 数-波数領域のデータが得られる. 波数ベクトルは波の 到来方向を示すことから，直達波と反射波が異なる方向 から伝わる場合は直達波と反射波を区別することができ， 反射波の到来方向を知ることができる. 次に座標 $x, y$ に 関する 2 次元フーリエ変換によって時間-波数領域へと 変換し，反射波の波数を持つ成分だけを抽出することに よって，加振点から損傷を通って計測点に伝わる波の伝 播時間を推定することができる. 以上のように, 波数領 域の情報を用いることで，反射波の到来方向および伝播 時間を推定し，損傷を検出する手法を提案する.

\section{2. 損傷検出手法の概要}

本章では, 提案手法の概要を, 平板を対象とした数值 解析の結果を示しながら説明する.

\section{(1) 解析概要}

\section{a) 解析対象構造物}

対象構造物は幅 $500 \mathrm{~mm} \times$ 奥行き $400 \mathrm{~mm} \times$ 厚さ $6 \mathrm{~mm}$ の 平板とした. 図-1において, 幅方向を $x$ 軸, 奥行き方向 を $y$ 軸とし, 左側手前を原点とする，材質はアルミニウ ムで, 密度は $2.7 \mathrm{~kg} / \mathrm{m}^{3}$, 縦波速度は $6400 \mathrm{~m} / \mathrm{s}$, 横波速度は $3170 \mathrm{~m} / \mathrm{s}$ とした. 3 次元有限要素法を用いて， $2.5 \mathrm{~mm}$ $\times 2.5 \mathrm{~mm} \times 1.5 \mathrm{~mm}$ のソリッド要素でモデル化した. 健全モ デルの総要素数は 128000 である。境界条件として, 底 面の 4 隅の 3 自由度を固定した。計算時間間隔は, $1.0 \times 10^{-7}$ 秒，継続（計測）時間は $1.0 \times 10^{4}$ 秒とした。応答 に $5 \%$ の正規乱数を与えた.

\section{b) 加振 $\cdot$ 計測条件}

板の上面側において加振・計測をすることとする. 図 -2 のように, 構造物の $\mathrm{A}$ 点 $(x=200 \mathrm{~mm}, y=200 \mathrm{~mm})$ において 最大振幅が 1.0 で中心周波数 $150 \mathrm{kHz}$ の Ricker Wavelet を 外力として鉛直方向に与え, 鉛直方向の加速度応答を計 測領域 B $(x=290 \mathrm{~mm}-307.5 \mathrm{~mm}, y=190 \mathrm{~mm}-207.5 \mathrm{~mm})$ におい て $2.5 \mathrm{~mm}$ 間隔の格子状に配置した計測点で計測するこ とを想定し，数值計算によって波形を得た. 計測データ の開始時刻は，図-2の入力波の 0 秒に一致寸るとした. 計測点は, $x$ 方向 8 点, $y$ 方向 8 点の計 64 点である. 減 衰は剛性比例型でモデル化し, 加振波の中心周波数 $150 \mathrm{kHz}$ における減衰定数が $1 \%$ となるうに設定した.

\section{c) 損傷モデル}

損傷はジョイント要素でモデル化した閉口亀裂を対象 とした，閉口亀裂とは，損傷が閉じる時には力を伝達し， 開くときには力を伝達しない復元力特性を有する損傷で ある. 損傷の初期状態では閉口亀裂となり，閉口亀裂を 放置すると切り欠きの様な完全に開いた状態になると考 え, 閉口亀裂を解析対象とした。損傷の大きさは, 幅 $5 \mathrm{~mm} \times$ 深さ $6 \mathrm{~mm}$ とした．本章では，格子内に損傷がある 場合と，格子外に損傷がある場合を想定する．格子内に 損傷がある場合の損傷位置は, D2 $(x=300 \mathrm{~mm}-305 \mathrm{~mm}$, $y=200 \mathrm{~mm})$ する. なお, $(x=300 \mathrm{~mm}-305 \mathrm{~mm}, y=200 \mathrm{~mm})$ は, 亀 裂が $=200 \mathrm{~mm}$ の位置に， $x=300 \mathrm{~mm}-305 \mathrm{~mm}$ にかけて $5 \mathrm{~mm}$ の亀裂が $x$ 方向に伸びていることを示す．亀裂の開く方 向はy方向である. 格子外に損傷がある場合の損傷位置 は, D3( $x=250 \mathrm{~mm}-255 \mathrm{~mm}, y=250 \mathrm{~mm})$ とする.

\section{(2) Lamb波}

\section{a) Lamb波のモード}

Lamb 波には，図-3 のように $z$ 軸を上下方向にとった ときに，上下対称に変位する伸縮型（S モード）と上下 反対称に変位する屈曲型（A モード）が存在し，それぞ れ複数のモードが存在する.

\section{b) 位相速度 · 群速度}

縦波速度が $6400 \mathrm{~m} / \mathrm{s}$ ，横波速度が $3170 \mathrm{~m} / \mathrm{s}$ のアルミニ ウム平板の位相速度および群速度の分散曲線を図-4,5に 示寸. 0 次モード（青），1次モード（緑），2次モード （赤），3 次モード（水色）, 4 次モード（紫， $\mathrm{S}$ モー ドのみ表示）である. 横軸は周波数と板厚の積である.

周波数と板厚の積が約 $2 \mathrm{MHz} \cdot \mathrm{mm}$ 以下（板厚 $6 \mathrm{~mm}$ の 場合は約 $333 \mathrm{kHz}$ 以下）であれば，S0 モードまたは A0 モードだけが存在するように設定することができる．本 研究で与えた中心周波数 $150 \mathrm{kHz}$ の Ricker Wavelet をフー リエ変換したところ, 約 $450 \mathrm{kHz}$ 以下の成分を有するが, 約 $300 \mathrm{kHz}$ の以上の振幅は相対的に小さいことから, 主 に S0 モードと A0 モードが対象となると考えられる. また本研究では, 約 $300 \mathrm{kHz}$ までを考慮できるような要 素サイズを使用している. S0 モードと A0 モードのどち らが励起されるかについては，例えば平板上面のある点 において $z$ 軸方向に打撃力を与えた場合, 励起される主 なモードは図-3(b)のような A モードになると考えられる. これを確かめるため, $x, y$ 座標が同じ位置で板の上面と 下面での応答をそれぞれ求め, 応答の和を 2 で割ったも のを $\mathrm{A} 0$ モード，差を 2 で割ったものを $\mathrm{S} 0$ モードと考え たところ，A0 モードに比べて S0 モードの振幅は 1/100 程度になることを確認し, 本研究の解析では主に $\mathrm{A} 0$ 次 モードを励起していることを確認した. 減衰定数 $1 \%$ を 採用したが，減衰定数の值を変えても損傷検出の可能性 に関して導かれる結論に変更はないことを確認している. 


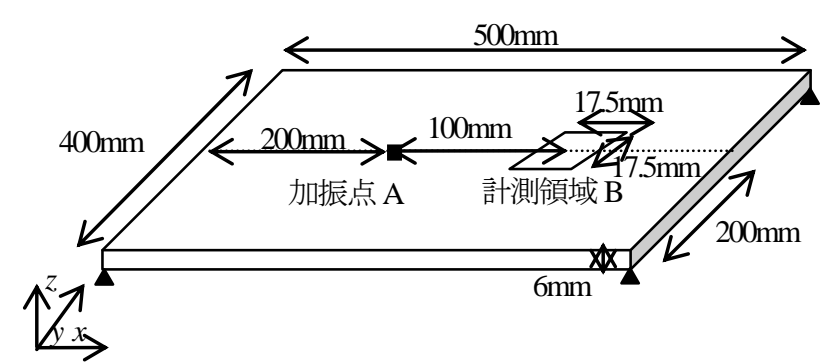

図-1 解析対象構造物（アルミニウム平板）

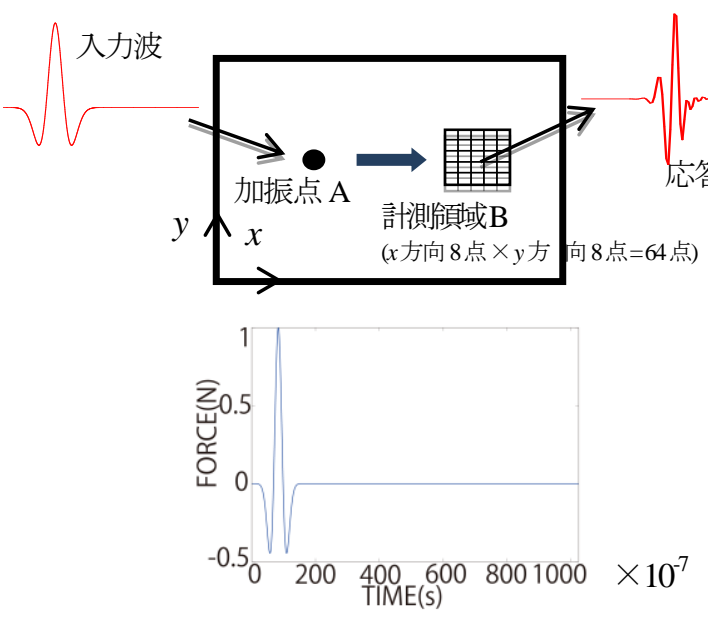

図-2 加振 ・計測条件（上）と入力波（下）

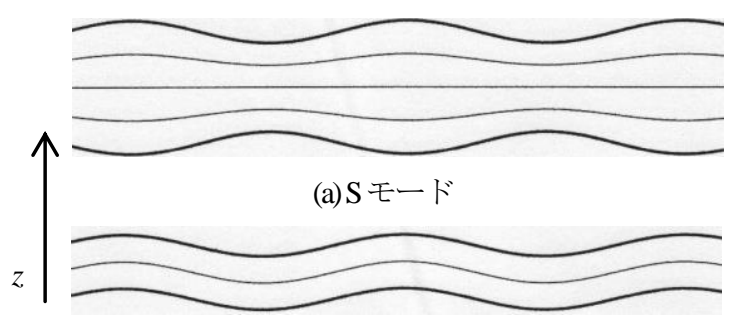

(b) A モード

図-3 Lamb波の2つのモード

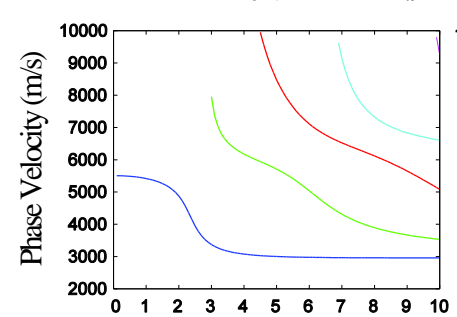

Freq $\cdot$ Thickness $(\mathrm{MHz} \cdot \mathrm{mm})$

(a) $\mathrm{S}$ モート

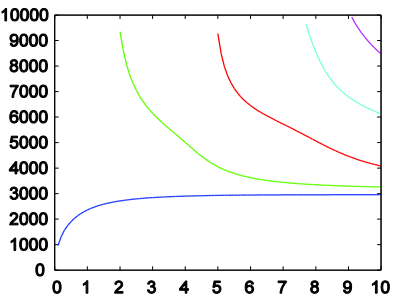

Freq $\cdot$ Thickness $(\mathrm{MHz} \cdot \mathrm{mm})$

(b)A モード
図-4 位相速度の分散曲線

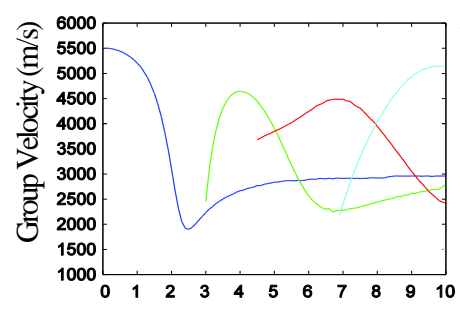

Freq $\cdot$ Thickness $(\mathrm{MHz} \cdot \mathrm{mm})$ (a) $\mathrm{S}$ モード

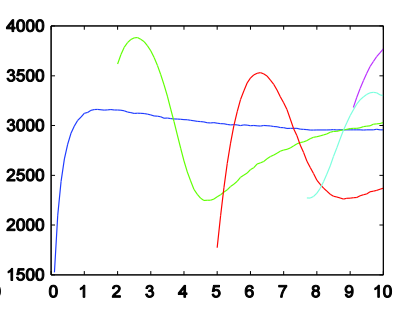

Freq $\cdot$ Thickness $(\mathrm{MHz} \cdot \mathrm{mm})$ (b)A モード 図-5＼cjkstart群速度の分散曲線

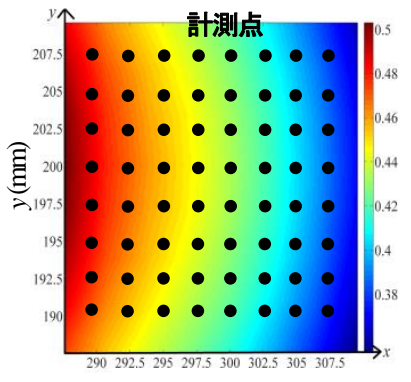

$x(\mathrm{~mm})$

(a)損傷がない場合

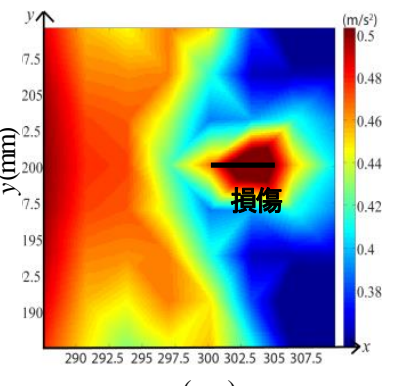

$x(\mathrm{~mm})$ (b)計測領域内 D2 に損傷がある場合

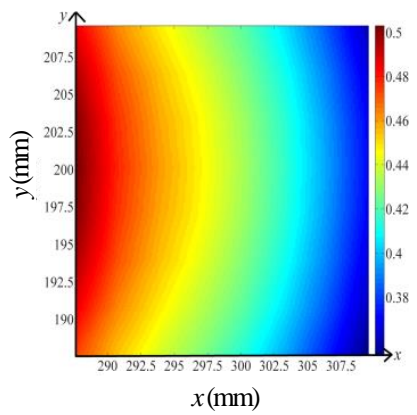

(c)計測領域外 D3 $(x=250-252.5 \mathrm{~mm}, y=250 \mathrm{~mm})$ に損傷がある場合

図-6 計測領域内の加速度パワーのコンター図

\section{(3) 計測領域内の損傷検出手法（空間領域）}

損傷がある場合は，加振点から伝わった波が損傷箇所 で散乱され，損傷部において大きな応答が得られると考 えられ，既往の実験でもこのことが確認されている．よ って，計測領域内に損傷がある場合，各計測点の応答を 相互に比較し，相対的に応答の大きな箇所を調べること で，格子内の損傷を検出することが出来ると考えられる． 計測点 $(x, y)$ の時刻 $t$ における鉛直方向の加速度応答を $w(x, y, t)$ とすると, そのパワー $P(x, y)$ は次式となる.

$$
P(x, y)=\int_{0}^{T}\{w(x, y, t)\}^{2} d t
$$

ここに $T$ は計測時間である. 本研究では, 各計測点の加 速度応答からパワーを求め, パワーのコンター図から応 答の大きい䇢所を推定することで，計測領域内の損傷の 有無の判断と, 損傷位置を推定することとする. 以上の 損傷検出手法は，パワーの空間的な違いから損傷を検出 するので，本研究では空間領域の手法と呼ぶこととする.

図-6に，損傷がない場合と，計測領域内の $\mathrm{D} 2(x=300$ $-302.5 \mathrm{~mm}, y=200 \mathrm{~mm}$ ) に損傷がある場合と, 計測領域外 の D3 $(x=250-252.5 \mathrm{~mm}, y=250 \mathrm{~mm})$ に損傷がある場合のパワ 一のコンター図を示寸. 計測領域内に損傷がない場合

（図-6(a)）は，計測領域の左にある加振点から波動が同 心円状に伝播していることが見てとれる.これに対し， 計測領域内に損傷がある場合 (図-6(b)) は, 損傷箇所で 波が散乱して応答が大きくなるため，損傷位置に大きな パワーが出ている. 計測領域外に損傷がある場合（図6(c)）は，損傷がない場合（図-6(a)）とほぼ同じグラフ である.この理由は, 加振点から同心円状に伝わる直達 

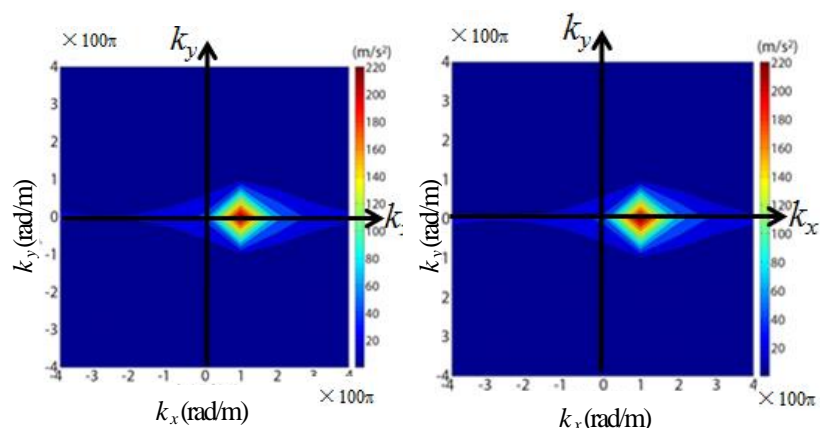

(a)損傷がない場合 (b)計測領域外 D3 に損傷がある場合

図-7 加速度の 3 次元フーリエ変換のコンター図

(フィルタリング前，周波数 $150 \mathrm{kHz}$ に着目)

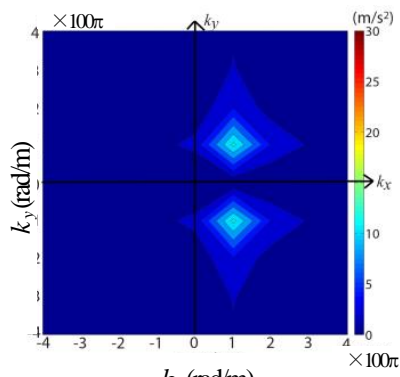

$k_{x}(\mathrm{rad} / \mathrm{m})$

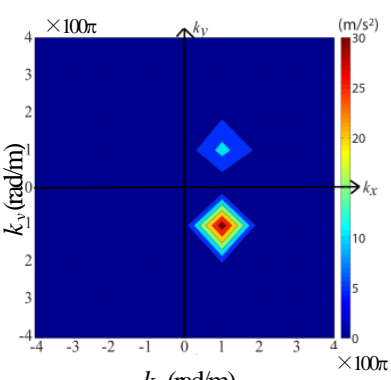

$k_{x}(\mathrm{rad} / \mathrm{m})$ (a)損傷がない場合 (b)計測領域外 D3 に損傷がある場合

図-8 加速度の 3 次元フーリエ変換のコンター図

(フィルタリング後，周波数 $150 \mathrm{kHz}$ に着目)

波の影響が反射波の影響よりはるかに大きく，パワーの 違いとしてほとんど表れないためであると考えられる.

以上から，空間領域の損傷検出手法により，計測領域 内の損傷を検出することができる．計測領域内に損傷が ないと判断された場合は，次項の波数領域の手法に移る.

\section{(4) 計測領域外の損傷検出手法（波数領域）}

\section{a) 3次元フーリエ変換}

加速度応答の 3 次元フーリエ変換を行い, 時間 $t$ を周 波数 $\omega$ に，座標 $x, y$ を波数 $k_{x}, k_{y}$ に変換する. その結果, 加速度応答は, $w(x, y, t)$ の時間-空間領域加 $W\left(k_{x}, k_{y}, \omega\right)$ の 周波数-波数領域へと変換される.

$W\left(k_{x}, k_{y}, \omega\right)=\iiint w(x, y, t) \exp \left(-i\left(\omega t+k_{x} x+k_{y} y\right)\right) d x d y d t$

損傷がない場合と計測領域外 D3 に損傷がある場合の 加速度応答の 3 次元フーリエ変換 $W\left(k_{x}, k_{y}, \omega\right)$ を図-7 に示 す. 中心周波数が $150 \mathrm{kHz}$ の Ricker Wavelet で加振を行っ ているため, 固有円振動数 $\omega=2 \pi \times 150,000=300,000 \pi(\mathrm{rad})$ に 対する 3 次元フーリエ変換を横軸に波数 $k_{x}$, 縦軸に波数 $k_{y}$ をとり示す．位相速度 $3000 \mathrm{~m} / \mathrm{s}$ の A0 モードが卓越して いることから, いずれも $k_{x}=100 \pi, k_{y}=0$ で最大值を示し ており，似た形状となっている．波数べクトル $\left(k_{x}, k_{y}\right)$ は， 波動の伝播方向を示すので，y方向の波数が 0 で， $x$ 方 向の波数が正であるということは，計測領域で計測され
た波は $x$ 軸の正の方向に伝播し $y$ 方向には伝播していな いことを示す．すなおち，加振点からの直達波の影響が 大きく，反射波の影響がみられないことがわかる．なお， 計測領域は $2.5 \mathrm{~mm}$ 間隔で 8 点であるので，3 次元フーリ 工変換によって得られる波数の刻みが約 $100 \pi$ 間隔と荒 くなっている. そのため, $-400 \pi,-300 \pi,-200 \pi,-100 \pi, 0 \pi$, $100 \pi, 200 \pi, 300 \pi, 400 \pi$ のなが，実際の波数に最も近い波 数成分のところが卓越することとなる. なお，入力波は 他の振動数成分も有するので，他の振動数とそれに対応 する波数についても同様の傾向が見らえるが，中心周波 数 $150 \mathrm{kHz}$ に相当する成分の振幅が最も大きく誤差も小 さいと考え，150kHzに着目して考察する.

\section{b)フィルタリングによる直達波除去と反射波の到来方向の推定}

計測領域外 D3 に損傷がある場合，加速度応答には， 加振点から直接伝わった直達波と, 損傷箘所で反射され て伝わった反射波とが混在しているが，直達波の影響が 大きいために反射波の影響が見えずらいものと考えられ る、そこで，反射波を取り出すため，直達波を取り除く フィルターをかける。

$$
\begin{aligned}
& W\left(k_{x}, k_{y}, \omega\right)=\varphi\left(k_{x}, k_{y}\right) \times \\
& \iiint w(x, y, t) \exp \left(-i\left(\omega t+k_{x} x+k_{y} y\right)\right) d x d y d t
\end{aligned}
$$

ここに， $\varphi\left(k_{x}, k_{y}\right)$ は，直達波を取り除くフィルターであり 次式で表す.

$$
\varphi\left(k_{x}, k_{y}\right)=\left\{\begin{array}{l}
0: \text { if } \quad k_{y}=0 \\
1: \text { otherwise }
\end{array}\right.
$$

図-1,2 の配置では，直達波は $x$ の正方向に伝わり $y$ 方 向には伝わらないことから, 波数 $k_{x}$ が正で波数 $k_{y}$ が 0 と なる成分を取り除けば直達波を除去できると考えられる. しかし，図-7から見て取れるように，波数 $k_{x}$ が負で波数 $k_{y}$ が 0 となる， $x$ の負方向に伝わる成分もわずかに存在 し，反射波の影響より大きい。この理由として波が加振 点から同心円状に伝わる際に，減衰などにより波形形状 が変化し，箇所毎に異なった波形が観測されるため, こ の波形形状の変化が負側に伝わる成分としてとらえられ， 波数 $k_{x}$ が負の成分にも值を持つものと考えたが，今後 検証したい，そこで，本研究では水平方向に伝わるす心゙ ての成分を除去することとした.

図-8 に，損傷がないときと損傷が計測領域外 D3 にあ るときのフィルタリング後の 3 次元フーリエスペクトル を示す．直達波は同心円状に伝わるため，フィルタリン グによって直達波を完全に取り除くことができない.し かし，損傷のない場合は図-8 が上下対称となっているの に対し，損傷がある場合は反射波があるため上下非対称 となる. 第 4 象限で值の大きいところの波数 $k_{x}=100 \pi, k_{y}=$ $-100 \pi$ 文射波の波数であることから，反射波の到来方 向がわかる（ここでは左上から伝わることがわかる）。 


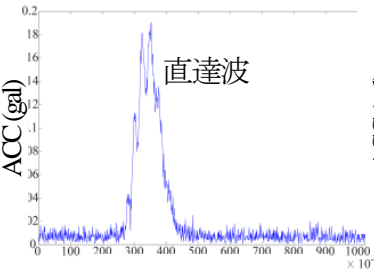

time(s)

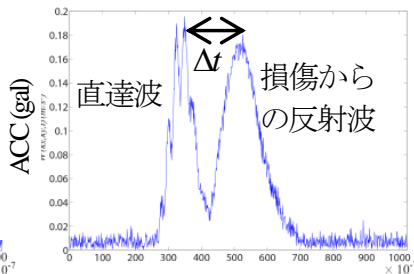

time(s) (a)損傷がない場合 (b)計測領域外 D3に損傷がある場合

図-9 加速度の 2 次元フーリエ変換 $\hat{W}\left(k_{x}, k_{y}, t\right)$ の時刻歴図

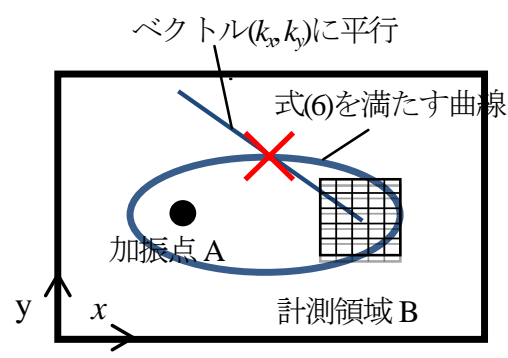

図-10 損傷位置の推定

c) 2次元フーリエ変換による損傷の存在領域の検出

次に, 加速度応答を座標に関して 2 次元フーリエ変換

し，b)で読み取った反射波の波数 $k_{x}=100 \pi, k_{y}=-100 \pi に$ 対 する時刻歴を求める.

$$
\hat{W}\left(k_{x}, k_{y}, t\right)=\iint w(x, y, t) \exp \left(-i\left(k_{x} x+k_{y} y\right)\right) d x d y
$$

図-9にその時刻歴を示寸，損傷がない場合は，加振点 から同心円状に伝わった直達波のみが現れ，損傷が D3 にある場合は損傷からの反射波も現れるので，図-9(b)か ら直達波と反射波の到来時間の差 $\Delta t$ を読み取る．加振 点 $\mathrm{A}$, 計測領域 $\mathrm{B}$ の中心点, 損傷 $\mathrm{D} 3$ の位置を $\mathrm{A}\left(a_{x}, a_{y}\right)$, $\mathrm{B}\left(b_{x}, b_{y}\right), \mathrm{D}\left(d_{x}, d_{y}\right), \mathrm{Lamb}$ 波の群速度を $c_{g}$ とすると，損傷 位置に関する等式が成立する.

$$
\begin{aligned}
& \sqrt{\left(d_{x}-a_{x}\right)^{2}+\left(d_{y}-a_{y}\right)^{2}}+\sqrt{\left(d_{x}-b_{x}\right)^{2}+\left(d_{y}-b_{y}\right)^{2}} \\
& =\sqrt{\left(a_{x}-b_{x}\right)^{2}+\left(a_{y}-b_{y}\right)^{2}}+c_{g} \Delta t
\end{aligned}
$$

\section{d) 損傷位置の推定}

図-8(b)において振幅が最大となる波数べクトルから反 射波の到来方向がわかるので，図-10 のように計測領域 からどの方向に損傷があるかがわかる．次に，図-9(b)か ら読み取れる $\Delta t$ から描ける式(6)から，図-10 のように損 傷の存在する位置を曲線で表すことができる．この曲線 と損傷の方向を示寸直線との交点として，損傷の位置を 推定することができる.

\section{(5) 提案する損傷検出手法のまとめ}

本研究の提案手法の概要は以下の通りである.

(1)：ある点Aにおいて瞬間的な衝撃波を与え，格子状に 配置した計測領域Bにおける加速度応答を計測する。

(2) : 損傷位置で波が散乱し，応答が大きくなることから， 各計測点における加速度応答のパワーのコンター 図から計測領域内に存在する損傷を検出する.
(3) : 計測領域内に損傷が存在しないならば, 各計測点に おける応答を $(x, y, t)$ に関して3次元フーリエ変換し， 直達波を除去するフィルタリングを行い，卓越す る波数ベクトルを読み取ることによって，損傷か らの反射波の到来方向を特定する.

(4) : 各計測点における応答を $(x, y)$ に関して2次元フーリ 工変換し，(3)で得られた損傷からの反射波の波数 成分に着目し，そのスペクトルを時間ステップご とにプロットすることによって損傷を通った波の 到来時間がわかるので, 損傷の存在し得る領域を 図化することができる.

(5) : (3)の反射波の到来方向, (4)の損傷の存在し得る領域 を図化し，両者の交点として損傷位置を検出する.

\section{3. 提案手法の妥当性検証}

本章では，2章と同じアルミニウム平板を対象とし， 損傷の位置を様々に変えたケースに対して数值解析を行 い, 提案手法の妥当性を検証する.

\section{(1) 検討ケース}

損傷位置と計測領域の位置関係から，図-11のように 損傷位置の異なる9通りのケースを想定した。 ケース1は

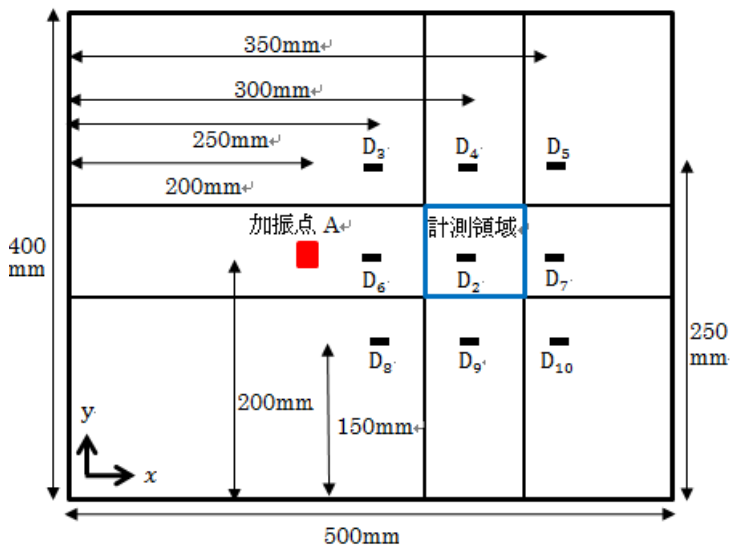

図-11 加振点(赤) と計測領域 (青) と損傷 $\left(\mathrm{D}_{2} \sim \mathrm{D}_{10}\right)$ の位置関係

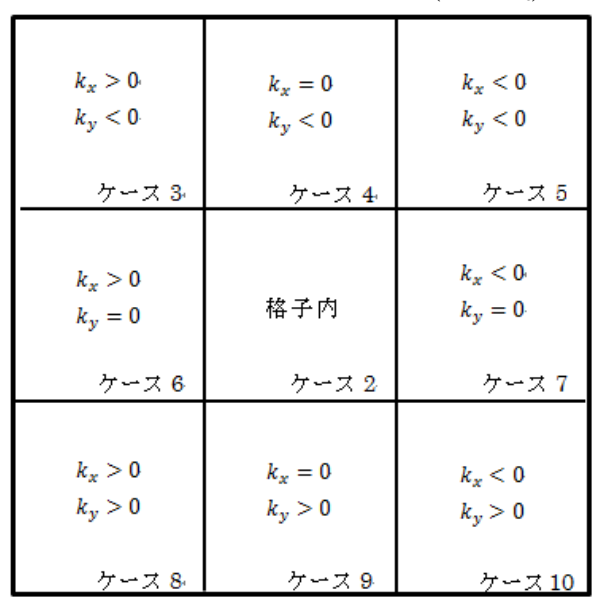

図-12 損傷位置毎の損傷からの反射波の波数 
表-1＼cjkstart各ケースの損傷位置

\begin{tabular}{|c|c|c|}
\hline ケース名 & 亀裂方向 & 損傷位置 \\
\hline ケース2 & $x$ & $\mathrm{D} 2(x=300-302.5 \mathrm{~mm}, y=200 \mathrm{~mm})$ \\
\hline ケース3 & $x$ & $\mathrm{D} 3(x=250-252.5 \mathrm{~mm}, y=250 \mathrm{~mm})$ \\
\hline ケース4 & $x$ & $\mathrm{D} 4(x=300-302.5 \mathrm{~mm}, y=250 \mathrm{~mm})$ \\
\hline ケース5 & $x$ & $\mathrm{D} 5 \mathrm{x}(x=350-352.5 \mathrm{~mm}, y=250 \mathrm{~mm})$ \\
& $y$ & $\mathrm{D} 5 \mathrm{x}(x=350 \mathrm{~mm}, y=250-252.5 \mathrm{~mm})$ \\
\hline ケース6 & $x$ & $\mathrm{D} 6(x=250-252.5 \mathrm{~mm}, y=200 \mathrm{~mm})$ \\
\hline ケース7 & $x$ & $\mathrm{D} 7(x=350-352.5 \mathrm{~mm}, y=200 \mathrm{~mm})$ \\
\hline
\end{tabular}

損傷のないケース，ケース 2 は計測領域内に損傷がある ケースである。ケース3-10は計測領域外に損傷のあるケ 一スであり，損傷からの反射波の $x$ 方向の波数 $k_{x}$ の符号 と，y方向の波数 $k_{y}$ の符号の組み合わせの異なる 8 ケース である．ケース2-10の損傷位置をD2-D10とする，ケース 3-10の損傷から計測領域までの反射波の到来方向の波数 から明らかとなる波数の符号を，図-12に示す。

\section{(2) 解析結果}

各損傷位置のケースに対して，提案手法により損傷 を検出できるかどうか検証した．解析モデルの対称性か ら，ケース8-10はケース3-5と同じ結果が得られた。また, ケース 2,30 解析結果については既に2章で述べたので, ここではケース47の結果を述べる，各ケースの損傷位 置を表-1に示す．ケース5以外は，亀裂の長さがx方向に 伸びているケースとy方向に伸びているケースで同様の 結果が得られたので， $x$ 方向に伸びているケースのみ結 果を示す。ケース5については，亀裂の長さがy方向に伸 びているケースの方が明瞭に損傷を検出できたので，y 方向の結果についても示す．なお，閉口亀裂だけでなく， 開口亀裂についても検討したが，反射波の振幅が異なる だけで，同様の結果が得られた。

\section{a) ケース4}

図-2のケース4の位置に $x$ 方向に伸びた損傷がある場合 のフィルタリング後の3次元フーリエ変換を図-13左に示 す.上下非対称であり，前述の通り波数の刻みが荒いた めに明瞭でないが， $k_{x}=0, k_{y}=100 \pi て ゙ は$ 振幅がほぼ0である

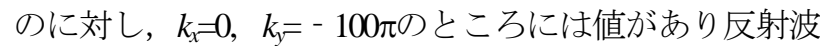
の成分が確認できる.この波数から，上から下に反射波 が伝播していることとがわかり，損傷の位置は上方向に あることが推定できる．この波数に対して，2次元フー リエ変換の時刻歴波形を図示すると，図-13右のように なる，直達波と反射波の時間差を読み取り，前章で述べ た方法で損傷の存在する範囲がわかり，到来方向と組み 合わせることで損傷位置D4を特定することができた.

\section{b) ケース 5}

図-2のケース5の位置に $x$ 方向に伸びた損傷がある場合 のフィルタリング後の3次元フーリエ変換を図-14左に示 す。損傷からの反射波は，左下方向に伝わることになる
ので， $k_{x}=-100 \pi, k_{y}=100 \pi の$ 位置に反射波の影響が現れる ことになるが，図-14左から明瞭に見えない. 図-14右に この波数における2次元フーリエ変換の時刻歴波形を図 示する. 3次元フーリエ変換において $k_{x}=100 \pi, k_{y}=100 \pi$ に しか現れない成分についても，2次元フーリエ変換では $k_{x}=-100 \pi, k_{y}=100 \pi の$ 項に表れるため，同心円状に伝わる 直達波の影響が表れている。これに比べて反射波の影響 は大変小さいことがわかる，この理由は，亀裂の向きが $x$ 方向であるので，計測領域に反射波がほとんど伝わら ないためであると考えられる.

次に，y方向に伸びた損傷がある場合ののフィルタリ ング後の3次元フーリエ変換を図-15左に示す. $k_{x}=-100 \pi$, $k_{y}=100 \pi の$ 位置に反射波の影響が現れており，損傷から の反射波は，左下方向に伝わっていることがわかるので， 損傷の位置が右上方向にあることが推定できる。図-14 右にこの波数における2次元フーリエ変換の時刻歴波形 を図示する．直達波と反射波の時間と群速度から損傷の

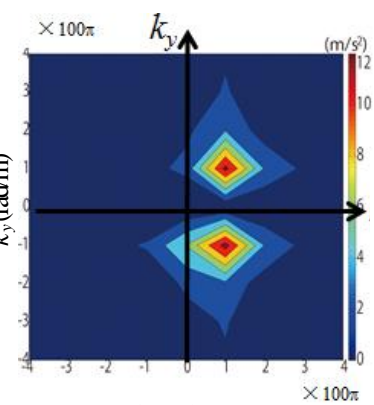

$k_{x}(\mathrm{rad} / \mathrm{m})$

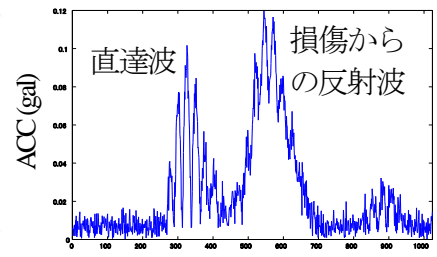

time $(\mathrm{s}) \quad \times 1.0 \times 10^{-7}$
図-13 フィルタリング後の3次元フーリエ変換（左）と反射波 の波数に着目した2次元フーリエ変換時刻歴（右）（ケース4）
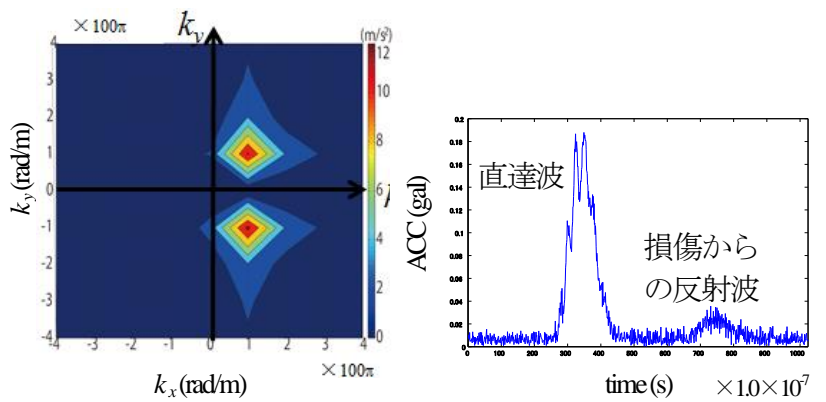

図-14 フィルタリング後の3次元フーリエ変換 (左) と反射波の波数に 着目した2次元フーリエ変換時刻埗（右）（ケース5，亀裂好向）

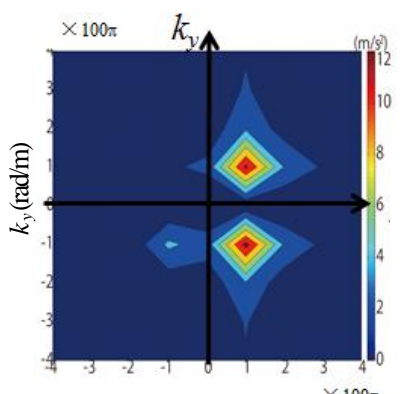

$k_{x}(\mathrm{rad} / \mathrm{m})$

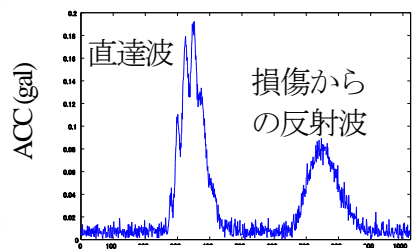

time (s) $\quad \times 1.0 \times 10^{-7}$
図-15 フィルタリング後の3次元フーリエ変換 (左) と反射波の波数に 着目した2次元フーリエ変換时刻楚 (右) (ケース5, 亀裂方向) 

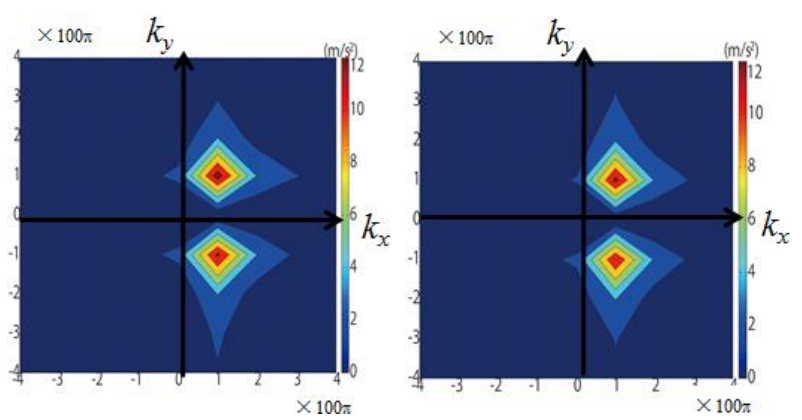

図-16 フィルタリング後の3次元フーリエ変換 (左 : ケース6, 右 : ケース7)

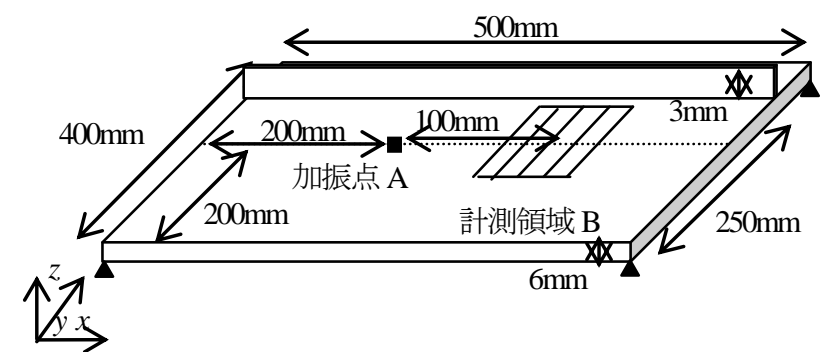

図-17 解析対象構造物（リブを有するアルミニウム平板）

存在する領域が推定でき，反射波の到来方向と合わせる ことで，損傷の位置を推定することができた．なお群速 度は, 平板の物性值が既知であると仮定し, 波動方程式 から導出した図-5の分散曲線から求めた．亀裂の向きが $y$ 方向の場合は, $x$ 方向の場合に比べて損傷からの反射波 の影響が大きいため，検出に成功したものと考えられる. このように，損傷の位置が同じでも亀裂方向によっては 反射波の伝播の程度が異なってくるため，損傷を検出で きる場合とできない場合のあることがわかった.

c) ケース6とケース7

図-2のケース6と7の位置に $x$ 方向に伸びた損傷がある 場合のフィルタリング後の3次元フーリエ変換を図-16に 示す．ケース6は計測領域から見たときに損傷が加振点 と同じ方向にあり，ケース7は計測領域から見たときに 損傷が加振点と逆方向にあり, 本研究のフィルタリング では反射波も除去してしまい，損傷を検出できなかった。

\section{(3) まとめ}

計測領域内に損傷があるケース2の場合は空間領域の 方法で検出できた．計測領域外のうち，ケース $3,4,8,9$ の損傷は， $x$ 方向に伸びた亀裂も $y$ 方向に伸びた亀裂も， 反射波の影響が計測領域に伝わるため，提案した波数領 域の手法により損傷位置を特定できた。しかし，ケース 5,10の損傷は， $x$ 方向に伸びた亀裂では反射波の影響が 計測領域に伝わりにくいため, 損傷の検出は難しいが, $y$ 方向に伸びた亀裂であれば，反射波が計測領域に伝わ るため, 波数領域の手法で検出できることがわかった. ケース6,7は，フィルタリングにより反射波の影響も除 去されるため, 損傷を検出寸ることはできなかった.

\section{4. リブを有する平板を対象とした妥当性検証}

\section{(1) 解析概要}

本節では，図-17 に示寸幅 $500 \mathrm{~mm} \times$ 奥行き $400 \mathrm{~mm} \times$ 厚 さ $6 \mathrm{~mm}$ の平板の上に，長さ $500 \mathrm{~mm} \times$ 幅 $5 \mathrm{~mm} \times$ 高さ $3 \mathrm{~mm}$ のリブがある構造物を対象とした．リブは，平板の手前 から $250 \mathrm{~mm}$ 奥側に設置した. リブの材料定数と要素サ イズは平板と同じで，リブ底面とリブのついた平板の節 点は共有とした. 材質, 加振・応答条件, 入力波は平板 を対象とした数值解析と同じとした.

\section{（2）損傷位置}

損傷がリブの奥側にあり目視で検出できない状況を想 定し，D11 $(x=250-252.5 \mathrm{~mm}, y=300 \mathrm{~mm})$ の位置に損傷を仮定 した。比較のため, 損傷のないケースの解析も行った。

\section{(3) 解析結果}

図-18に，健全時と損傷がある場合の計測領域中央に おける加速度波形の比較を示寸．直達波の後ろにリブに よる反射波が見られる．両者の形は似ており，損傷によ る影響はほとんど見られない，リブによる反射波は，リ ブ位置での散乱やモード・コンバージョンによって励起 された他モード等を含むと考えられる。

次に, 図-19に，フィルタリング後の3次元フーリエ 変換を示す．両モデルとも上下非対称であるのは，リブ からの反射波があるためである.リブからの反射波が現 れている $k_{x}=50 \pi, k_{y}=-50 \pi に つ い て, 2$ 次元フーリエ変換の 時刻歴波形を図示したものが図-20である. 両モデルと も，直達波の後ろに，リブからの反射波がみられる，リ ブからの反射波の後ろの時刻歴を比較すると，健全モデ ルでは直達波が到来する前の振幅と同程度であり，応答 がほとんどないことがわかるが，損傷モデルではわずか に損傷からの反射波が確認できる.

健全モデルと損傷モデルの2次元フーリエ変換を比較 することができれば，非常にわずかな差が確認できるた め, リブの後ろの損傷を検出できる可能性がある．健全 モデルのデータがない場合は，図-21のようにリブに沿 って計測を行うことで，相対的にリブの後ろの応答の大 きいところを検出することで，リブの奥側の損傷を検出 できる可能性があると考えられる.

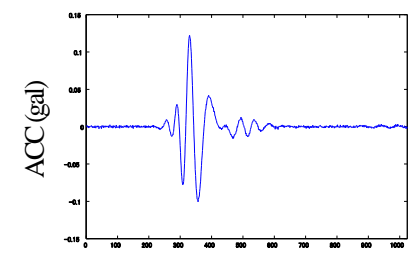

time(s) $\quad \times 1.0 \times 10^{-7}$

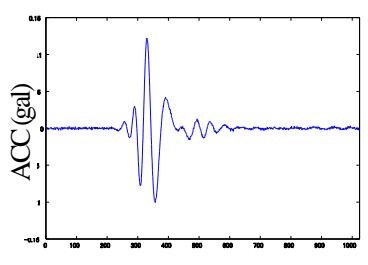

time $(\mathrm{s}) \quad \times 1.0 \times 10^{7}$
図-18 計測領域中央にお沙る加速度波形 (左: 健全, 右 : 損傷) 

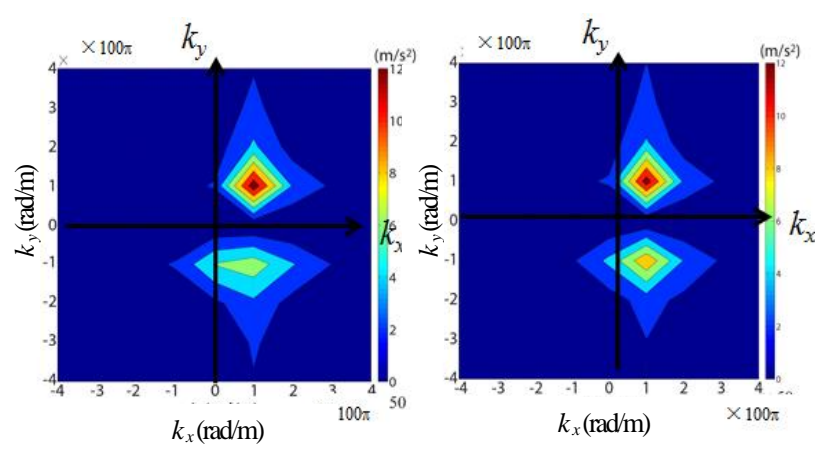

図-18 計測領域中央の加速度波形（左 : 健全，右 : 損傷)
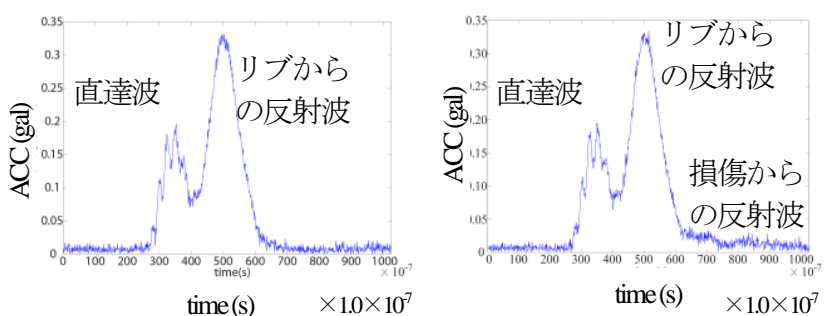

図-20 反射波の波数に着目した 2 次元フーリエ変換時刻歴 (左 : 健全, 右 : 損傷)

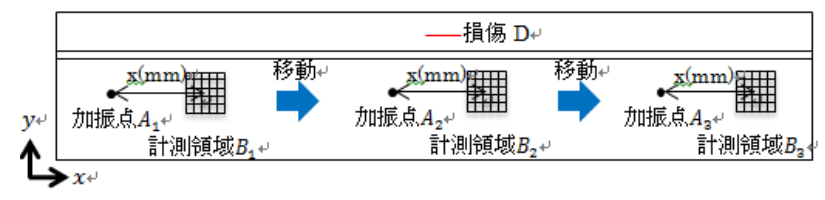

図-21 健全モデルがない場合のリブの奥側の損傷検出

\section{5. まとめ}

本研究では，格子状に配置した複数の計測点における 応答を利用した構造物の損傷検出手法を提案した．提案 手法は，空間領域における情報だけでなく，波数領域に おける情報も利用し，フィルタリングによって直達波を 除去して損傷部からの反射波を分離することによって， 損傷を検出するものである. 加速度応答を3次元フーリ エ変換したものをフィルタリングにより直達波を除去し た後の卓越する波数から，反射波の到来方向がわかるた め, 損傷の存在する方向がわかる. また，2次元フーリ 工変換を卓越する波数に着目して時刻歴波形を描くこと で，直達波と反射波の到達時間の差がわかり，損傷の存 在する領域が推定する. 損傷の方向と存在する領域を組 み合わせることで，損傷の位置が推定できる.

数值計算により検証を行った結果, 反射波が計測領域 内まで到達し，かつ直達波と反射波の到来方向が異なる 場合は，提案手法により損傷の位置を推定することがで きた.リブの奥側に存在する損傷については，リブによ
る反射波の影響が大きく損傷による反射波の影響が相対 的に小さいが，健全時との応答を比較したり，リブに沿 って箇所毎の応答を比較することができれば，損傷の有 無を検出できる可能性がある.

本研究では, 波動伝播論に基づく考察が十分に行えて いないので, 今後の課題としたい. また，要素サイズを より細かくして解析精度を上げ，計測点数や計測間隔を 変えた場合の結果の差異や，損傷と計測領域の位置関係 の影響などについて，今後詳細な検討を行っていきたい. 解析上励起させやすかったA0モードを採用したが，き 裂の開閉口を誘発させるには，面内の圧縮・引張を偏向 とするS モードが物理的直感として有用だと思われるの で，今後はSモードを用いることも検討したい.

\section{参考文献}

1) 阪神高速道路(株)：鋼床版疲労損傷への取り組み http://skill.hanshin-exp.co.jp/library/mainte/22104.html

2) P. Cawley, D. Alleyne: The use of Lamb waves for the long range inspection of large structures, Ultrasonics 34 , 287-90, 1996.

3) J.L. Rose: A baseline and vision of ultrasonic guided wave inspection potential, Journal of Pressure Vessel Technology, vol.124, 273-282, 2002.

4) 林高弘, 長尾将弘, 村瀬守正 : 超距離伝播するガイ ド波による損傷画像化, 日本機械学会論文集（A 編）， 72 巻 724 号, pp.131-138, 2006.

5) H.W. Park, H. Sohn, K.H. Law, C.R. Farrar : Time reversal active sensing for health monitoring of a composite plate, Journal of Sound and Vibration, Vol. 302, pp.50-66, 2007.

6) R.Gangadharan, C.R.L.Murth. S.Gopalakrishnan, M.R. Bhat: Time reversal technique for health monitoring of metallic structure using Lamb waves, Ultrasonics, 49, 696705, 2009.

7) M. Fink: Time reversal in acoustics, Time reversal in acoustics, Volume 37, Issue 2, 95-109, 1996.

8) R.K. Ing, M. Fink : Time reversed Lamb waves, IEEE Transactions on Ultrasonics, Ferroelectrics, and Frequency Control, Vol. 45, no. 4, 1998.

9）古川愛子, 丣島啓太, 清野純史 : 時間反転法に基づ く平板構造物の損傷検出に関寸る研究, 土木学会論 文集 A2(応用力学), Vol. 68, No. 2, I_69-I_80, 2012.

10) Y.K An, B. Park, H. Sohn: Complete noncontact laser ultrasonic imaging for automated crack visualization in a plate, Smart Material Structures, 22, 1-10, 2013.

(2014.6. 20 受付) 


\section{STUDY ON DAMAGE DETECTION TECHNIQUE FOR PLATE STRUCTURES IN THE SPACE AND WAVE-NUMBER DOMAIN}

\section{Aiko FURUKAWA, Keita KOJIMA and Junji KIYONO}

This study proposes a damage detection technique in the space and wave-number domains. A tone burst force is input to a structure at one point and the acceleration responses are measured at gridiron points. If the damage is inside the grid, the position of damage is detected from the contour of the acceleration power in the space domain. If the damage is outside the grid, its position is detected in the wavenumber domain through the 3D and 2D Fourier transforms. Numerical analysis was carried out on a plate structure, and the effectiveness is verified. 